\title{
Sustainability-driven innovation in China: The case of Windoor
}

\author{
Dmitrij Slepniov' and Lv Ping²
}

'Department of Business and Management, Aalborg University; ${ }^{2}$ School of Management, University of Chinese Academy of Sciences

\begin{abstract}
Introduction
1978 marked the start of a new era in China's history - a period of new reforms and opening up with significant implications for both China and the world. In the past three decades, the country has experienced tremendous economic growth and transformation which was initially driven by manufacturing and China becoming the 'factory of the world' and the largest exporter of manufactured goods. However, China's ascendancy in global manufacturing is now coming under increased pressure. The array of drivers behind this drop-off is extensive and includes a domestic rise in labour costs, a deceleration in economic growth and an improvement in the supply base in low cost South East Asia economies and elsewhere. Furthermore, Chinese government policy incentives centred on innovation, competitiveness and strengthening of domestic brands have encouraged many Chinese companies to look at the opportunities that innovation offer. The vision of the Chinese Government is encapsulated in the words of president $\mathrm{Xi}$ Jinping, delivered at the 18th Meeting of the Academicians of the Chinese Academy of Sciences: 'Seeking innovation-driven development is a natural choice if we are to adopt to changing developmental conditions... We must seize the time, because wait-and-see produces nothing and imitation gets us nowhere...' (Xi 2017).
\end{abstract}

What are the distinctive strategies that Chinese companies pursue when exploring innovation in general and in sectors where energy and sustainability issues particularly loom large? What are the implications of their efforts? How well are we equipped theoretically to understand and explain these processes? These are some of the questions that this chapter tackles.

The study employs an in-depth single case study of Orient Sundar Group, a manufacturing company from Gaobeidian in China's Hebei province. The company, whose current activities are predicated on the slogan "Making building more energy efficient, making life better!", is at the centre of the Gaobeidian Passive House project. This project is one of the largest Passive House initiatives in the world. The project brings together technology and expertise from a range of best-in-class specialized suppliers from all over the world and helps to advance our understanding of how to scale energy efficient building. Our study chronicles the transition of the company from a low-cost manufacturer to an advanced Passive House system integrator and reveals new paths to innovation that are supported by the unique context of China's ecological modernization (Stubbs and Cocklin 2008; Bohnsack 2018).

Drawing on a multidisciplinary approach and borrowing perspectives from business model innovation (Chesbrough 2010; Zott et al. 2011), global innovation networks (Dicken et al. 2001; Mudambi 2008; Haakonsson and Kirkegaard 2016) and sustainable development (Hart and Milstein 1999; Bansal and Roth 2000; Kirin et al. 2013; Yang and Jiang 2019), we investigate a case of local sustainability-driven innovation. This drive to innovate emerged in response to Chinese government policies for developing sustainable buildings and features business model innovation based on network orchestration capabilities. This chapter heeds the calls for new conceptual perspectives as well as more empirical cases on business models for sustainability (e.g. Schaltegger et al. 2016).

The chapter comprises three main parts. First, the theoretical background section introduces the conceptual basis of the paper. Second, we examine empirical insights into the case study. Finally, we present an analysis and discussion, and conclude with the key lessons and implications for future research.

\section{Study context and theoretical basis}

\section{Ecological modernization}

Dealing with sustainability-related challenges is a pressing necessity worldwide. In recent decades, China has attracted wide attention due to, on the one hand, the severity of its environmental challenges and, on the other, its distinctive set of effective strategies to tackle these challenges. Mckinsey Global Institute (Woetzel et al. 2019) estimated that China has been the world's largest source of carbon emissions since 2006. Indeed, in 2019 China accounted for 28 percent of annual global carbon emissions. At the same time, China has been striving to counteract potential negative environmental impacts of rapid industrialization. In 2017, the country invested around USD 127 billion or 45 percent of the global total in these efforts. That is three times more than the combined investment of the USA and Europe (Woetzel et al. 2019).

Sustainable development has been high on the agenda of the Chinese government for quite some time (World 
Bank 2013; Yang and Jiang 2019). Recently it was given particular prominence in the country's 13th Five-Year plan. For example, the plan stated the objective of doubling GDP between 2011 and 2020 without doubling energy usage. Further, the long-term focus on achieving environmental targets is reflected by the formation of a new unit of central government, the Ministry of Ecology and Environment.

These ambitious sustainable development targets are dependent on continuous industrial upgrading and the emergence of an innovation ecosystem that enables independent business actors to identify common ground for cooperation and innovation that can foster the harmonious co-existence of business, societal and environmental sustainability, i.e. delivering on all dimensions of the Triple Bottom Line. The notion of the Triple Bottom Line has been around since the 1990s, and is underpinned by the idea that a company's success not only depends on its financial performance, but also on the environmental and social contributions it makes.

Stubbs and Cocklin (2008) conceptualize a sustainability business model as one where sustainability becomes the key driving force of the company and determines its decision making. In this conceptualization the dominant neoclassical model of the company is transformed so that economic performance goals become subordinate to the primary goals of environmental and social performance. The sustainability business model is informed by an ecological modernization perspective, i.e. a paradigm of decoupling economic growth from environmental degradation through environmental policies, innovation and new technologies (Stubbs and Cocklin 2008). In this regard, China offers a particularly rich context for advancing our understanding of sustainability-driven innovation beyond the usual approach to sustainable development based on philanthropy, corporate social responsibility and product innovation.

\section{Emerging business models for sustainability in China}

As the Chinese ecosystem for innovation in sustainable technologies is still not sufficiently mature to drive radical innovation, it at least in part relies on links with global innovation networks (Haakonsson and Slepniov 2018). Chinese industrial actors are developing strategies to tap into knowledge and technology globally through strategic alliances, joint ventures and acquisitions. Planning entirely new cities from scratch, actors in the construction industry can combine and test new technologies, and more importantly, they are able to combine old technologies in new ways, over time creating a new path for radical innovation. This emerging business model reflects unique industryand system-level attributes and highlights a new value creation logic, and potentially new governance forms, that contribute to knowledge and ideas that transcend boundaries between value co-creating actors.

This pathway is facilitated by policies supporting strategic industries, which has seen Chinese companies evolve from being followers towards becoming global market leaders, and in some cases technology leaders. This evolution is not necessarily based on internal resources and capabilities. Rather, it is due to the ability to connect the dots of global capabilities in innovation and integrating them into new solutions relevant to the local context (Haakonsson and Kirkegaard 2016). This approach is at the core of the case study we examine in this chapter.

Global targets for carbon dioxide emissions, the visible increase in air pollution in Chinese cities, a still growing economy and, not least, a growing demand for energy, has put China in a position where following is no longer an option and existent technology packages do not suffice. To achieve the sustainable transition required, a gradual accumulation of capabilities and simply catching up is no longer a viable strategy. Indeed, China needs to develop radical solutions for which the technological and innovation capabilities do not yet fully exist, even in advanced economies.

In sustainable housing, incumbent companies from the Global North are highly specialised in specific technological segments, such as windows, doors, roofs, insulation and energy optimisation. An array of technologically specialized companies compete against each other in their home markets, where most houses are old and are being slowly renovated to reduce carbon dioxide emissions. These companies compete in their niches when introducing 'green' or 'sustainable' solutions to the market for green renovation, striving to convince their customers to invest in one specific technology over another. Due to this competitive model, incumbent lead-companies do not have a history of collaboration and they are not organized in networks, as is the case in other sustainable industries, such as the wind turbine industry. Sustainable housing companies are internationalized to some degree, but mostly in terms of their market, through exploitation strategies.

The Chinese context is characterized by a completely different dynamics. Chinese cities are growing and national, regional and local governments have given leading companies the mandate to develop, test and build sustainable houses and entire cities from scratch. In the planning of new suburban areas around the larger cities, the directive is clear: houses should produce the same amount or more energy than they consume. This housing type is termed 'passive houses' or 'zero-energy houses'. The overall plan is to construct entirely new suburban sustainable towns along railways around large Chinese metropoles. The ultimate goal is to achieve a comprehensive sustainable solution that, over time, has the potential to contribute to urban development beyond China. This is a unique opportunity to 'build from scratch', to develop urban solutions to sustainability issues without having to take into account existing infrastructure. Rather, sustainable designs can be introduced from the very start of the planning phase. Let us take a closer look at one of these initiatives in China and the company behind it. 


\section{Methodology and case study}

\section{Case study strategy of inquiry}

As mentioned above, we conducted our research in the form of a single case study design (e.g. Eisenhard 1989; Yin 2018). The study applies this investigative method with the aim of providing in-depth insights into a contemporary phenomenon in its real-life context. By using a qualitative approach we also seek to contribute to a growing body of qualitative research coming out of China. Interest in the case study research method in East Asian contexts has been on the rise recently, but is still lagging behind quantitative approaches (Tsou 2012; Shi and Au-Yeung 2015).

The authors have followed the company since August 2017 and the case study has been developed by drawing on multiple sources including interviews, archival records, site visits and meeting notes.

\section{Case study}

\section{How it all began}

Orient Sundar Group - the company behind Windoor is a Chinese private construction company founded in 1988 by Shouqiang Ni in Gaobeidian, Hebei Province. Mr. Ni's venture started as a carpentry company with initial capital of RMB 4800 and eight employees. At the start, the business focused on manufacturing windows for the local market. A decade after its establishment, the company had 310 employees and was registered under the name Orient Sundar Window \& Door Co., Ltd.

By the 1990s, China was rapidly establishing itself as the largest manufacturer and consumer of architectural doors and windows. There are more than 30,000 players in the Chinese doors and windows construction industry. The industry is highly fragmented and none of the players, including Windoor, can boast occupying a noticeable market share of the domestic market. The company's founding family quickly realized that in order to survive and stand out in a very competitive industry, innovation and bringing new value to the market were key. Since its own RED capacity could only partially support the strategic ambitions that the management set out to achieve, the decision was made to focus on external sources of knowledge and learning through international collaborations.

\section{Rapid internationalization}

2004 marks the next important chapter in the company's history. Orient Sundar formed its first joint venture with a privately owned German company, Moser $\mathrm{GmbH}$. In 2005, Orient Sundar established another joint venture with Raico Technik GmbH, and in 2009 initiated international collaboration with M. Meesenburg KG from Germany. These close international partnerships signified the start of the internationalization and transformation journey that the company has been following ever since.

International collaborations were an excellent means to upgrade its status and capabilities. In 2012, the Minis- try of Science and Technology (MOST) granted Orient Sundar the title of 'National Scientific and Technological Cooperation Base'. In terms of physical space, the company significantly expanded. In 2013, the production facilities site and its surrounding areas were awarded the status of a 'National Construction and Green Technology Innovative International Zone'. The company fully embraced this opportunity, investing heavily in its own Window and Door technology RED centre as well as opening an on-site Experimental and Testing division. In 2016, the company established collaboration with the Passive House Institute in Germany and further expanded its international network to include new strategic partnerships in Austria and Italy.

Production and RED, however, were not the only focal points that the company was eager to advance, as activities directed towards the market and customer experience received increasing attention. For example, to enhance customer experience and brand awareness, the company opened the China Windows and Doors Museum on its premises. Furthermore, it also built China's first Passive House demonstration building to promote the concept of zero-energy building and highlight its possibilities for users and customers as well as collaboration opportunities for domestic and international partners. Over the years, the company managed to develop into a competent integrator and partner for foreign companies seeking access to the dynamic and challenging construction industry in China.

\section{From internationalization to innovation}

Since the early 2000s, the company has been developing its international cooperation with European companies. The joint ventures mentioned above provided a solid foundation for its internationalization strategy and the continuous expansion of its global network.

In 2016, during the Eighth German-Chinese Forum for Economic and Technological Cooperation, the Orient Sundar Window Group signed the Sino-German Enterprises cooperation agreement with the European Building Hardware Association. The company also participated in activities conducted under agreements between the German Rosenheim Research Centre and China Academy of Building Research.

In 2012, on its premises in Gaobeidian, the company started organizing international trade fairs for windows and doors related industries, attracting more than 600,000 attendees representing business partners, government officials, academic institutions from China and more than 20 foreign countries.

All these efforts earned the Orient Sundar Group a reputation as a dynamic international partner capable not only of attracting investment for its windows manufacturing operation, but also of bringing together best-inclass actors from the global construction industry. Over the years, the company's premises in Gaobeidian have significantly expanded into Windoor City, a permanent 
exhibition which hosts 112 foreign companies and more than 300 domestic companies, creating a physical space to collaborate and gain access to Chinese market knowledge and product development platforms.

\section{Organising international sustainability-driven innovation} Only a small fraction of China's buildings are built in an energy efficient way, which presented a significant opportunity for the Orient Sundar Group and its partners clustered in the Windoor City Innovation Park. The company divided the park into three bases (Energy-saving Windows Base, Ultra-low Energy Consumption Building Base, China-EU Building Energy Saving Base) and four centres (Window and Accessories Exhibition Centre, Quality Test Centre, Warehouse and Logistics Centre and National Green Intelligent Building Science-Technology Experience Centre). The park also hosts ten professional exhibition halls displaying the latest technology for energy-saving windows and doors systems, energy-saving materials, building heat preservation systems and energy-saving ventilation equipment.

In 2013, the company constructed its first Passive House demonstration building on its premises. In 2015, apartments were constructed using multiple technologies from the Passive House project. In 2016, the company was recognized as both a 'Chinese passive ultra-low power green building industry demonstration base' and a "Hebei province building energy-saving new technology and new product demonstration base'.

In 2018, the company's in-house R\&D department had 170 employees and by 2019 this number had risen to 220, accounting for approximately ten percent of its total workforce Over the years, the company has registered more than 300 patents and received multiple certificates, including the German Passive House Research Institute (PHI) certification, the Energy Star certification and the Chinese Energy-saving identity authentication.

\section{Changing role of manufacturing}

Manufacturing capabilities were crucially important for the company from its inception. In recent years, the Orient Sundar Group reorganized its manufacturing base with clear divisions between different levels of demand groups. The high volume lower market end windows were produced at the largest production site in Windoor city, while the Sino-German joint venture, Shunda Moser Doors and Windows, manufactures for the mid- and highend markets. Both sites closely collaborate with the company's R\&D operations and have access to its international partners' base at Windoor City. In 2017, new lines were added with a focus on energy-efficiency, and niche and complementary products, such as ventilation systems, glazing, heat insulation and sun shading systems.

\section{Discussion and contribution}

Windoor represents an example of sustainability-driven innovation built on bringing together technology from a range of locations and specialized suppliers into a larger system, the Passive House. Several lessons can be distilled from Windoor's journey.

China's unique conditions and urgency for environmental modernisation created conditions conducive for new innovation and business models. The Gaobeidian project alone comprises 330,000 square meters of certified Passive House buildings, including high rises, multifamily buildings, villas, offices and retail space. The scale is impressive and rivals anything outside China. Perhaps it is less domestic technological prowess, and more speed, scale and ability to collaborate that led to rapid change in the industrial structure, and in the longer run is likely to create new areas of dynamic comparative advantage.

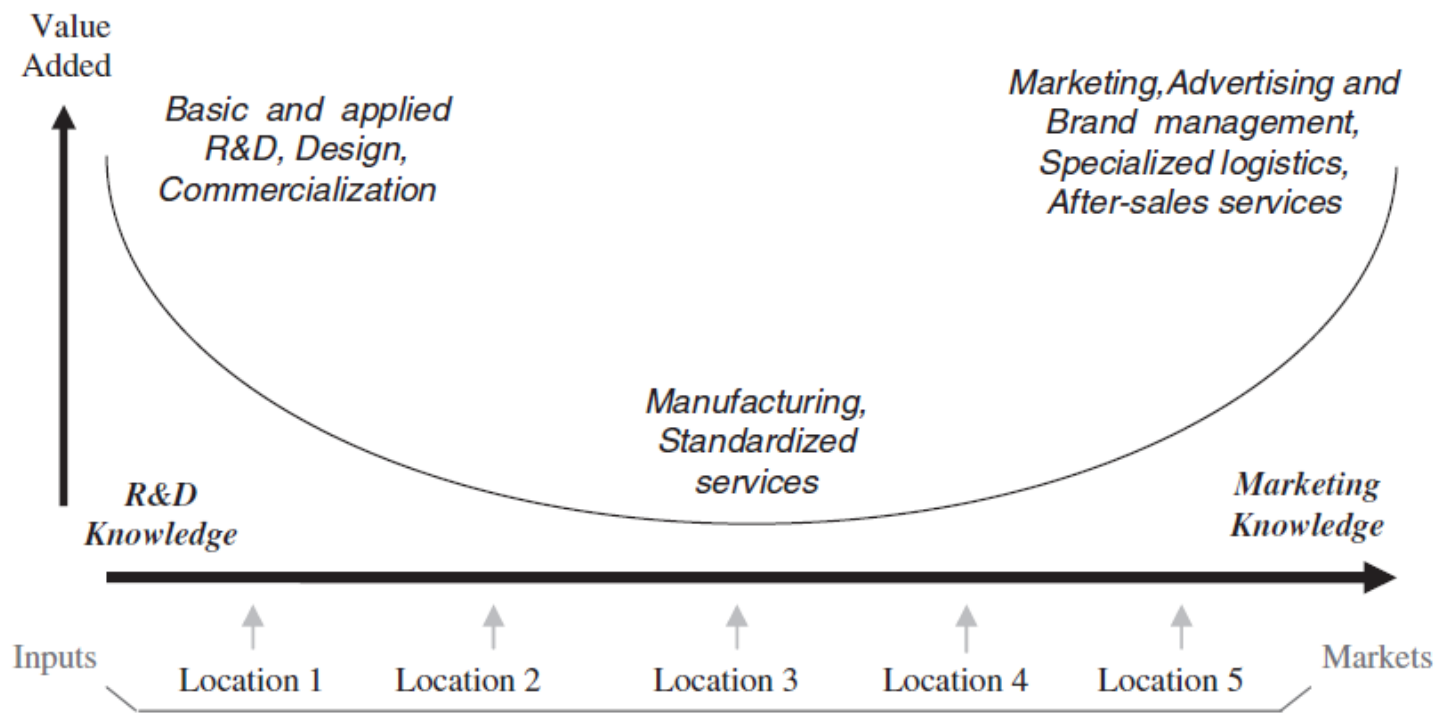

Figure 1 Value chain disaggregation (Mudambi 2008) 
The company actively prepared to respond to a window of opportunity provided by government policies and national standards for climate-robust green buildings and urban design to avoid locking in existing carbon footprints. This case not only presented commercial opportunities for the companies involved but might also provide valuable lessons for policy makers in other provinces of China and abroad.

The case also highlights the importance of emerging market actors in sustainability-oriented business models and the new roles they play. Understanding the development of emerging market actors has traditionally drawn on international business approaches that seek to understand topics such as the position of a company in global value chains and production networks, how to increase exports by linking up with global buyers and how to attract foreign direct investment to specific industrial sectors. Hence, we can assess the progress of companies and industries by examining to what extent they have upgraded to increase their participation in the value chain.

Innovation management literature related to emerging markets mainly analyses the dynamic and innovation capabilities of companies, while exploring how the institutional framework for innovation has played a role in the catching up process of domestic corporations. The literature argues that these innovation capabilities and frameworks have resulted from from transfers of technology and linking up with global buyers and suppliers. Figure 1, based on Mudambi (2008), illustrates how one study assessed the value chain of a specific product or company.

Windoor's development trajectory reveals a more nuanced journey in the company's rise from the bottom of the value curve. While Windoors RED output remained relatively limited compared to its European partners, the company still managed to establish itself as the leading player in the chain. The case demonstrates China's rise, and current industrial and leadership changes, as more value chains are becoming integrated the further downstream companies move, and there is a realization that radical innovation and new value creation may involve integration of different products and technologies not previously combined.

In order to become an industry leader, a company may not necessarily be dependent on cutting-edge technological expertise. Rather, leadership can also come about from taking on a coordinating role - building a new business model linking different types of (fragmented) technology into a systems solution. In other words, establishing global innovation networks that can be driven not only by companies from the developed North, but by emerging orchestrators from the developing South.

Technology transfer has become just one of several sources of innovation capability, with companies integrating diverse technologies into new products. Moreover, innovation may result from integrating technologies across value chains. In this case, focused on the complex production of sustainable buildings, the passive house, technologies taken from a range of value chains are braided into an assembly line of specialised technologies. As the literature states, moving downstream in a value chain increases the value added. Emerging market actors can take a lead through moving further down the wider value chain, beyond the confines of their own, specific value chain. In the case of Windoor, the company reached a point where products from different value chains complement each other and together provide system solutions, radical innovation and new approaches to environmental modernisation.

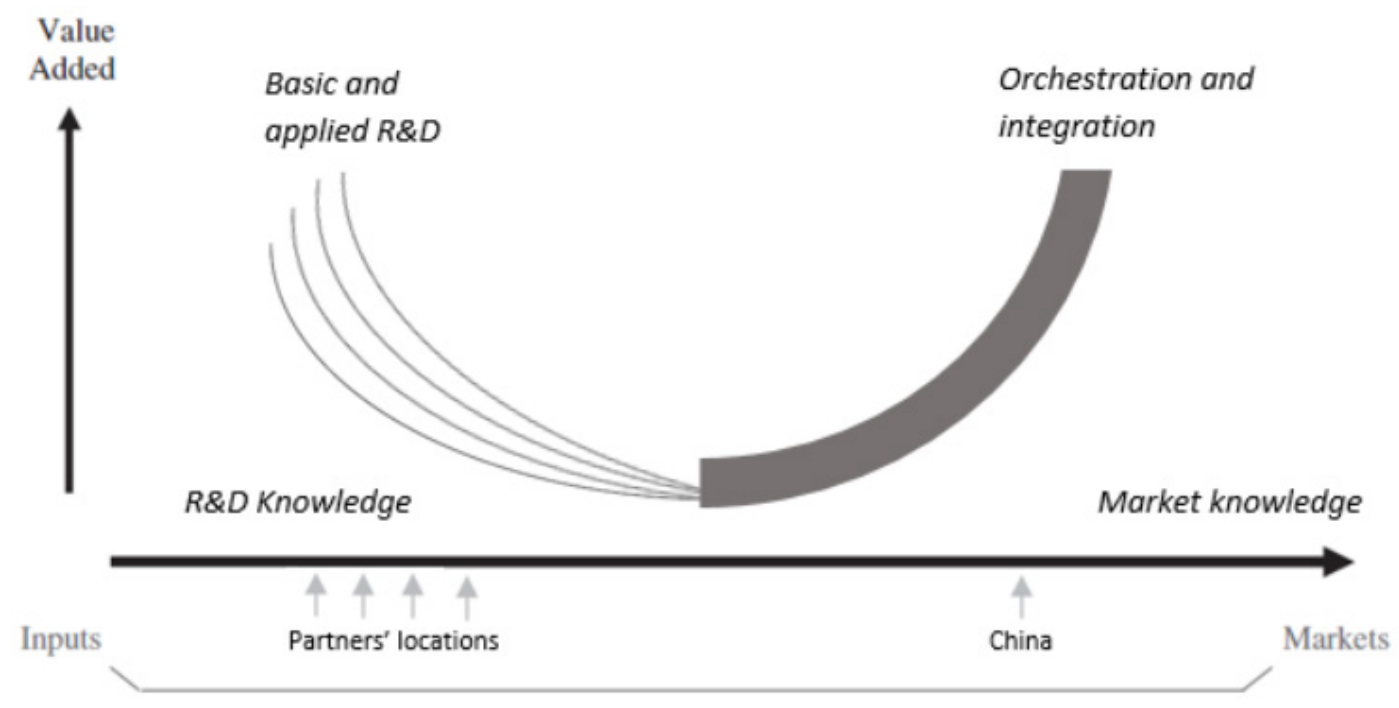

Figure 2 Windoor vlue chain disaggregation (author's creation) 


\section{References}

Bansal, P. and Roth, K. 2000. 'Why Companies Go Green: A Model of Ecological Responsiveness', Academy of Management Journal, 43(4): pp. 717-736.

Bohnsack, R. 2018. 'Local Niches and Firm Responses in Sustainability Transitions: The Case of Low-Emission Vehicles in China'. Technovation, (70-71): pp. 20-32.

Chesbrough, H. 2010. 'Business Model Innovation: Opportunities and Barriers'. Long Range Planning, 43(2-3): pp. 354-363.

Dicken, P., Kelly, P.F., Olds, K. and Wai-Chung Yeung, H. 2001. 'Chains and Networks, Territories and Scales: Towards a Relational Framework for Analysing The Global Economy'. Global Networks, 1(2): pp. 89-112.

Eisenhardt, K.M. 1989. 'Building theories from case study research'. Academy of Management Review, 14(4): pp. 53250.

Farrell, H. and Newman, A.L. 2020. 'Chained to Globalization: Why It's Too Late to Decouple'. Foreign Affairs, January/February: pp. 70-80.

Ferdows, K. 1997. 'Making the Most of Foreign Factories'. Harvard Business Review, 75(2): pp. 73-88.

Haakonsson, S. J. and Kirkegaard, J. K. 2016. 'Configuration of Technology Networks in the Wind Turbine Industry. A Comparative Study of Technology Management Models in European And Chinese Lead Firms'. International Journal of Technology Management, 70(4): pp. 281-299.

Haakonsson, S. and Slepniov, D. 2018. 'Technology Transmission across National Innovation Systems: The Role of Danish Suppliers in Upgrading the Wind Energy Industry in China'. European Journal of Development Research, 30(3): pp. 462-480.

Hart, S.L. and Milstein, M.B. 1999. 'Global Sustainability and the Creative Destruction of Industries'.

Sloan Management Review, 41: pp. 23-33.

Kiron, D., Kruschwitz, N., Haanaes, K., Reeves, M. \& Goh, E. 2013. 'The Innovation Bottom Line'. MIT Sloan Management Review, 54(3): pp. 1-33.

Mudambi. R. 2008. 'Location, Control and Innovation in Knowledge Intensive Industries'. Journal of Economic Geography, 8: pp. 699-725.

Paine, L.S. 2010. 'The China Rules'. Harvard Business Review, 88(6): pp. 103-108.
Santos, J. and Williamson, P. 2015. 'The New Mission for Multinationals'. MIT Sloan Management Review, 56(4): pp. 45-54.

Schaltegger, S., Hansen, E. G., and Lüdeke-Freund, F. 2016. 'Business Models for Sustainability: Origins, Present Research, and Future Avenues'. Organization \& Environment, 29(1): pp. 3-10.

Shi, J. and Au-Yeung, A. Y. S. 2015. 'An innovation perspective on Chinese retailers' competitive advantage'. International Review of Retail, Distribution and Consumer Research, 25(2): pp. 120-144.

Stubbs, W., and Cocklin, C. 2008. 'Conceptualizing a "Sustainability Business Model."' Organization \& Environment, 21(2): pp. 103-127.

Tobias. M. and Xue, B. 2015. Sustainability in China: Bridging Global Knowledge with Local Action. Basel: MDPI.

Tsou, H. T. 2012. 'Collaboration competency and partner match for e-service product innovation through knowledge integration mechanisms', Journal of Service Management, 23(5): pp. 640-663.

Woetzel, J. et al. 2019. China and the World: Inside the Dynamics of a Changing Relationship. Mckinsey Global Institute.

World Bank. 2013. China 2030 Building a Modern, Harmonious, and Creative High-Income Society. Washington, D.C: World Bank.

Xi, J. 2017. 'Build China into a World Leader in Science and Technology. In Xi Jinping, The Governance of China II'. Foreign Languages Press, Beijing, pp. 292-304.

Yang, M. and Evans, S. 2019. 'Product-service system business model archetypes and sustainability'. Journal of Cleaner Production, 220: pp. 1156-1166.

Yang, X. and Jiang, S. (eds.). 2019. Challenges Towards Ecological Sustainability in China. Cham: Springer.

Yin, R.K. 2009. Case Study Research - Design and Methods. Thousand Oaks, CA: Sage.

Zott, C., Amit, R., and Massa, L. 2011. 'The business model: Recent developments and future research'. Journal of Management, 37(4): pp. 1019-1042. 